\title{
INKLUZIVNE KNJIŽNIČNE USLUGE U MREŽI KNJIŽNICE TINA UJEVIĆA I KNJIŽNICE NOVI ZAGREB
}

\author{
THE INCLUSIVE LIBRARY SERVICES \\ IN THE LIBRARY NETWORKS OF THE TIN UJEVIĆ LIBRARY \\ AND THE LIBRARY NOVI ZAGREB
}

\author{
Tea Grašić-Kvesić \\ Knjižnice grada Zagreba \\ tea.grasic.kvesic@kgz.hr \\ Adela Ćurlić \\ Knjižnice grada Zagreba \\ adela.curlic@kgz.hr \\ Tihana Rašeta \\ Knjižnice grada Zagreba \\ tihana.raseta@kgz.hr
}

UDK / UDC 027.022 053.2 056.26:027.6(497.6 Zagreb)(091)

Stručni rad / Professional paper

Primljeno / Received: 5. 11. 2018.

Prihvaćeno / Accepted: 7. 2. 2019.

\section{Sažetak}

Cilj. Cilj je ovoga rada ${ }^{1}$ prikazati provođenje inkluzivnih knjižničnih usluga u narodnim knjižnicama kao što su mreža Knjižnice Tina Ujevića i mreža Knjižnice Novi Zagreb, koje su sastavni dio Knjižnica grada Zagreba. Rad je fokusiran na suradnju narodnih knjižnica i udruga osoba s invaliditetom i djecom s poteškoćama u razvoju kroz razdoblje od gotovo dva desetljeća.

1 Rad je prezentiran na 43. Skupštini Hrvatskoga knjižničarskog društva održanoj u Opatiji, 10.13. listopada 2018. Rad su prezentirale autorice Adela Ćurlić, Tea Grašić-Kvesić i Tihana Rašeta.

Vjesnik bibliotekara Hrvatske 62, 1(2019), 269-283

ISSN 0507-1925

(C) VBH 2018. 
Pristup/metodologija/dizajn. U uvodnom teorijskom dijelu rada opisana je uloga, zadaća i poslanje narodnih knjižnica, posebno u orijentaciji na skupine osoba s invaliditetom i ostale slične ranjive skupine potencijalnih korisnika narodne knjižnice. Slijedi prikaz suradnje dviju mreža narodnih knjižnica, mreže Knjižnice Tina Ujevića i mreže Knjižnice Novi Zagreb s ukupno 2 središnje knjižnice i 10 knjižničnih ogranaka, s velikim nizom udruga osoba s posebnim (dodatnim) potrebama kroz razdoblje od gotovo 20 godina. Posebno je istaknuta suradnja Knjižnice Tina Ujevića s Udrugom za promicanje inkluzije, dok mreža Knjižnice Novi Zagreb izlaže svoju aktivnost u dugogodišnjoj suradnji s Udrugom osoba s cerebralnom i dječjom paralizom (CeDePe).

Rezultati. Višegodišnji rad i suradnja ovih dviju mreža narodnih knjižnica s pojedincima i udrugama osoba s invaliditetom pokazuju da su inkluzivne knjižnične usluge već dugo prisutne u praksi naših narodnih knjižnica, a u današnje vrijeme one su postale nužnost s obzirom na djelovanje u skladu s ciljevima održivoga razvoja Agende 2030.

Društveni značaj. Mreže Knjižnice Tina Ujevića i Knjižnice Novi Zagreb promotori su miroljubivosti, socijalne osviještenosti i društvene aktivnosti te nastoje biti odgovorna i inkluzivna ustanova na svim razinama, što ovaj rad potvrđuje.

Originalnost/vrijednost. Ovaj rad prvi put sustavno na jednom mjestu donosi prikaz rada i primjere dobre prakse u radu i suradnji dviju mreža narodnih knjižnica, Knjižnice Tina Ujevića i Knjižnice Novi Zagreb, s velikim brojem udruga osoba s invaliditetom i u tom smislu može biti poticaj drugim knjižnicama da oblikuju svoju inkluzivnu knjižničnu djelatnost ili, još bolje, organiziraju onu koja već postoji.

Ključne riječi: Agenda 2030, inkluzija, narodne knjižnice, osobe s posebnim (dodatnim) potrebama, tjelesni invalidi

\section{Abstract}

Purpose. The paper presents the inclusive library services in public libraries such as the Tin Ujević and the Novi Zagreb library networks, which are an integral part of the Zagreb City Libraries. The article focuses on the collaboration of public libraries and associations of persons with disabilities and children with developmental difficulties over a period of almost two decades.

Approach / methodology / design. In the introductory theoretical part of the article, the role, tasks, and mission of public libraries are described, especially their orientation to groups of persons with disabilities and other similar vulnerable groups of potential users of public libraries. Furthermore, the collaboration of the two networks of public libraries, the Tin Ujević and the Novi Zagreb library networks, with 2 central and 10 library branches, and with a large number of associations of the persons with special (additional) needs over a period of almost 20 years is presented. The collaboration of the Tin Ujević library with the Association for Promotion of Inclusion is particularly prominent, while the Novi Zagreb library network - Sloboština library reports about their 
activities and the long-term cooperation with the Association of Cerebral and Pediatric Patients-CeDePe.

Fidings. The many years of work and cooperation of these two networks of public libraries with individuals and associations of persons with disabilities show that inclusive library services are something that our libraries have been practicing for years and that there is a growing need for these services considering the goals of sustainable development of the Agenda 2030.

Social implications. The Tin Ujević and the Novi Zagreb library networks are the promoters of peace, social awareness, social activity, and, as it is evident in this paper, they aim to be responsible and inclusive institutions at all levels.

Originality / value. This is the first systematic overview of the work and cooperation of the two networks of public libraries, Tin Ujević library network and Novi Zagreb library network with a large number of associations of persons with disabilities. It may serve as an example of good practice and encourage other libraries to organize their inclusive library activities or improve the existing ones.

Keywords: UN Agenda 2030, inclusion, public libraries, persons with physical disabilities, persons with special (additional) needs

\section{Uvod}

U ovom radu daje se prikaz inkluzivne knjižnične prakse u mreži Knjižnice Tina Ujevića i mreži Knjižnice Novi Zagreb prezentirane na 43. skupštini Hrvatskoga knjižničarskog društva s temom Uloga i mogućnosti knjižnica u ostvarivanju globalnih ciljeva održivog razvoja UN Agende 2030., održanoj u Opatiji od 10. 10. do 13. 10. 2018. u organizaciji Hrvatskoga knjižničarskog društva i suorganizaciji Knjižničarskog društva Rijeka i Gradske knjižnice Rijeka. Rad je fokusiran na suradnju knjižnica i udruga osoba $s$ invaliditetom i djecom s poteškoćama $u$ razvoju s obzirom na one aktivnosti koje su dio temeljnih zadaća narodnih knjižnica propisanih UNESCO-ovim Manifestom za narodne knjižnice i IFLA-inim smjernicama za narodne knjižnice te koje su dio provedbe ciljeva održivog razvoja Agende 2030. Globalni razvojni ciljevi univerzalni su i moraju biti primjenjivi u svim zemljama i zajednicama, uz uključivanje svih ljudi. Narodne knjižnice u njihovoj provedbi uzimaju u obzir specifične prilike, uvjete i mogućnosti u kojima one djeluju, nastoje prepoznati prioritetna područja djelovanja i sagledati vlastite mogućnosti pružanja doprinosa održivom razvoju diljem planeta. Na taj način narodne knjižnice žele biti dijelom globalnog partnerstva koje je ključno za realizaciju ciljeva, poglavito cilja 4 iz kojeg se navodi: 
"Važan podcilj je osigurati rodnu jednakost u obrazovanju te jednak pristup svim razinama obrazovanja i stručnoj obuci za ranjive grupe, uključujući osobe s invaliditetom i djecu u ranjivom položaju. “2

Glavne i osnovne odredbe Manifesta i IFLA-inih smjernica o ovoj temi jasno naglašavaju obavezu u radu narodnih knjižnica. Polje djelovanja narodnih knjižnica temelji se na mogućnosti zadovoljavanja potreba za obrazovanjem i pristupom znanju, informacijama i kulturnim dobrima čovječanstva kako bi se društvo slobodno razvijalo i napredovalo u ostvarivanju demokratskih prava građana, kako pojedinaca tako i društvenih skupina. Navodimo dio IFLA-inih smjernica za narodne knjižnice koje to jasno definiraju:

„Narodna knjižnica kao mjesni prilaz znanju osigurava osnovne uvjete za učenje kroz cijeli život, neovisno odlučivanje i kulturni razvitak pojedinca i društvenih skupina. Narodna je knjižnica mjesno obavijesno središte, koje svojim korisnicima omogućuje neposredan pristup svim vrstama znanja i obavijesti.“" ${ }^{\text {3 }}$

Stoga narodne knjižnice trebaju realizirati sve potrebne uvjete za one korisnike koji te uvjete nemaju, kao npr. prilaze knjižnici za osobe s invaliditetom, pristup računalu, slobodan pristup građi i informacijama.

Osim što pripisuju zadaće narodnim knjižnicama, već spomenute smjernice detaljno propisuju načine primjene tih zadaća kroz knjižnične službe, usluge i pristup informacijama na kojima knjižnice temelje svoj rad:

„Službe narodne knjižnice zasnivaju se na jednakosti pristupa svima, bez obzira na dob, rasu, spol, vjeru, nacionalnost, jezik ili društveni položaj. Posebne se službe i građa moraju osigurati za one korisnike koji se iz bilo kojeg razloga ne mogu služiti redovitim uslugama i građom, naprimjer za pripadnike jezičnih manjina, osobe s tjelesnim oštećenjima, bolesnike u bolnicama ili zatvorenike. “4

U skladu s navedenim, osobama koje nemaju mogućnosti posuđivati građu u samoj knjižnici, knjižnice pružaju uslugu dostave građe u suradnji s ustanovama kao što su bolnice, zatvori i umirovljenički domovi, ali uključuju i dostavu knjiga osobama u njihov dom ako nisu u mogućnosti doći do knjižnice.

Prema Manifestu, narodne knjižnice provode svoju zadaću na temelju kreiranja i vrednovanja uspješnosti socijalne integracije kao ključnog čimbenika socijalne, ekonomske, kulturne, civilizacijske i političke pravde za sve, kao i u pružanju

2 Novi izazov: globalni ciljevi održivog razvoja do 2030. Zagreb: Odraz, 2015. [citirano: 20191-24]. Dostupno na: http://www.odraz.hr/media/330673/globalni\%20ciljevi_or_final_web.pdf.

3 Narodna knjižnica: IFLA-ine i UNESCO-ove smjernice za razvoj službi i usluga / priredila radna skupina Sekcije za narodne knjižnice na čelu s Philipom Gillom; [s engleskoga prevela Irena Kranjec]. Zagreb: Hrvatsko knjižničarsko društvo, 2003. Str. [75]-77.

4 Isto. 
usluga onima koji imaju dodatne (posebne) potrebe te djeluju na ukidanju predrasuda prema osobama s invaliditetom.

Narodna je knjižnica, uz pomoć niza izvora i službi, na raspolaganju svim članovima zajednice te svim grupama korisnika. Jedna od njezinih osnovnih zadaća jest podržavanje obrazovanja tako što se omogućuje pristup znanju u raznim oblicima te daje podrška formalnom i neformalnom obrazovanju. Skupljanje, organiziranje, korištenje i pristup informacijama također su konstantna i važna zadaća knjižnica. Dalekosežno, ostvarivanje tih zadaća trebalo bi rezultirati pozitivnim utjecajem knjižnične djelatnosti na poboljšanje kvalitete života korisnika. Zadovoljavanje potreba i pružanje usluga djeci i mladima obveza je knjižnica jer na taj način knjižnica utječe na dječji razvoj i kvalitetu dječjeg života. Za narodnu knjižnicu najčešće je odgovorna lokalna vlast, pa je samim time knjižnica dio tkiva lokalne zajednice u kojoj želi biti aktivan i potreban element. Osim uloge baštinske institucije, vrlo je važna društvena uloga knjižnice, pa je za knjižnicu u tom smislu ključno da djeluje u interakciji s raznim društvenim grupama kao živahan čimbenik i pokretač zbivanja u već spomenutoj lokalnoj zajednici (kao „dnevna soba zajednice“, „treći prostor“ i sl.). Što se tiče zadovoljavanja potreba korisnika, teži se pristupanju svim grupama korisnika, pa tako i onim potencijalnima, koji još nisu korisnici knjižnice u pravom smislu riječi. Takve je korisnike potrebno identificirati i u taj proces naročito uključiti ciljnu skupinu osoba s invaliditetom (skupinu osoba s dodatnim potrebama). Knjižnice su mjesta koja sa svojim stručnim djelatnicima, novim tehnologijama i prostorom mogu pružiti potporu i uvjete za pristup informacijama, obrazovanju i kulturi onim korisnicima koji takve uvjete možda nemaju kod kuće i u tome se očituje osnovna zadaća knjižnica koja se kontinuirano provodi. Postojanje neusklađenosti između standarda uređenja narodnih knjižnica i potreba osoba s invaliditetom jest činjenica (npr. neodgovarajuća visina polica), no knjižničari postojeće stanje nastoje prevladavati svojim praktičnim radom te povećanjem svojih kompetencija za rad s takvim skupinama korisnika.

Već se pri samom uključivanju u pružanje usluga osobama s invaliditetom i poteškoćama u razvoju, u koordinaciji s mnogim specijalnim udrugama, knjižničari mreže Knjižnice Tina Ujevića i mreže Knjižnice Novi Zagreb susreću s problematikom definicije pojma invaliditeta. Pojava filozofije inkluzije i isključivo socijalnog modela (a ne medicinskog modela) dovodi do značajnih promjena u odnosu društva prema osobama s invaliditetom, posebice prema osobama s intelektualnim teškoćama. Tim pomacima s medicinskog modela na socijalni model značajno je pridonio i pokret samozastupanja osoba s invaliditetom koji se smatra jednim od najzanimljivijih i najpozitivnijih pokreta prošlog desetljeća uopće.

„Socijalni model, za razliku od medicinskog modela, prebacuje 'krivnju' invaliditeta s osobe s oštećenjem na 'nepravedno, okrutno društvo'. Danas je socijalni model stekao značajnu popularnost, osobito među onima koji su tradicionalno označeni kao 'nesposob- 
ni'. Uz podršku brojnih udruga za ljudska prava, neke od prepreka invaliditeta koje potječu od medicinskog modela pomalo su počele nestajati.“ 5

Naime medicinski model fokusira se isključivo na dijagnostiku, dok se socijalni model temelji na društvenoj inkluziji. Osobe s teškoćama svojim su samozastupanjem pokazale da imaju što reći ukoliko im se pruži prilika. One žele u potpunosti biti dio društvene zajednice te imati veću samostalnost, što knjižnice trebaju uzeti u obzir. Narodne knjižnice tako mogu sudjelovati u procesu rušenja predrasuda prema osobama s invaliditetom, koje su još na postulatima medicinskog modela koji govori o njihovoj „dijagnozi“ ili „liječenju“.

Praktična primjena socijalnog modela koji provode narodne knjižnice ostaje samo u okvirima teorije jer, kada se pokuša primijeniti u praksi, socijalni model kao takav postaje utopija. Koliko na praktičnu primjenu socijalnog modela utječu stereotipi, predrasude i vrijednosni sustav svakog čovjeka, bez obzira na zvanje i zanimanje koji ga u nekom smislu određuju te nepoznavanje suvremenih spoznaja o primjeni tog modela, još je uvijek pitanje na koje nema odgovora ${ }^{6}$ Naime poimanje prava osoba s invaliditetom u Hrvatskoj se još uvijek nalazi u okvirima medicinskog pristupa. Takav način razmišljanja itekako je vidljiv u usvajanju zakona kojim se osobama s invaliditetom prava osiguravaju na temelju njihovih nemogućnosti, a ne na temelju onoga što bi one mogle, željele i trebale.

\section{Definicija - problemi terminologije}

Pojam invalidnost odnosi se na vrste oštećenja, teškoće, smetnje ili nepravilnosti u fizičkom, psihičkom ili psihofizičkom smislu te nepravilnosti u socijalnom razvoju. Pojam defektnost ili defektan kao termin koji se često upotrebljava za pojedine osobe $\mathrm{s}$ invaliditetom ima vrlo negativan prizvuk jer u prvi plan ističe smetnju, ograničenost, nesposobnost. „Rječnik hrvatskoga jezika“ navodi pojam invalidan $\mathrm{kao}$ in - validan $=$ ne vrijedan ${ }^{7}$, pa bi ga zbog takve značenjske obojenosti ipak trebalo izbjegavati. Gojko Zovko osvrće se na termin hendikep koji se, s obzirom na njegovu etimologiju, također smatra neprikladnim: „Kao i termin hendikep - riječ koja dolazi iz engleskog jezika i kovanica je dviju riječi hand = ruka i cap = kapa, što asocira na povijesno težak položaj i siromaštvo osoba s invaliditetom, kada su ti ljudi s kapom u ruci prosili milostinju kako bi preživjeli." ${ }^{8}$ Članovi udruga osoba s posebnim potrebama preferiraju termin osobe s dodatnim

\footnotetext{
5 Mihanović, V. Invaliditet u kontekstu socijalnog modela. // Hrvatska revija za rehabilitacijska istraživanja 47, 1(2011), str. 74.

6 Mihanović, V. Nav. dj., str. 72.

7 Anić, V.; I. Goldstein. Rječnik stranih riječi. Zagreb: Novi liber, 2000., str. 616.

8 Zovko, G. Invalidi i društvo. // Revija za socijalnu politiku 6, 2 (1999), str. 106.
} 
potrebama, no u daljnjem tekstu služit ćemo se terminom osobe $s$ invaliditetom zbog pravno-administrativnih razloga koji im olakšavaju život u zajednici. Knjižničarska zajednica često upotrebljava i termin osobe s posebnim potrebama koji nerado koriste članovi udruga smatrajući kako im u društvu ne treba ništa posebno, već dodatno, jer posebnost smatraju više materijalnom i specijaliziranom kategorijom pojedinih osoba, dok se termin dodatno može odnositi na cijelu društvenu zajednicu, uključujući i osobe starije životne dobi, majke s malodobnom djecom i slične skupine.

\section{3. Što nam govori statistika - Republika Hrvatska i grad Zagreb}

Prema prikupljenim podacima Državnog zavoda za statistiku, u popisu stanovništva u Republici Hrvatskoj iz 2001. godine registrirana je ukupno 429421 osoba s invaliditetom (9,6 \% od ukupnog broja stanovnika). ${ }^{9}$ Prema izvješću Hrvatskog zavoda za javno zdravstvo (HZJZ) - Izvješće o osobama s invaliditetom u Republici Hrvatskoj iz 2016. - procjenjuje se da Hrvatska ima 511094 osobe s invaliditetom. Statistika grada Zagreba iznosi podatke da je u ukupnom broju od 800000 stanovnika $11,4 \%$ osoba s invaliditetom ili 90 260, a njih 2500 udruženo je u 34 udruge.

Kada se govori o statističkim podacima, treba uzeti u obzir kako je broj osoba s invaliditetom promjenjiva kategorija, kao i broj udruga. Opće osvještavanje društva dovelo je do toga da invalidne osobe mogu preko svojih lokalnih, mjesnih i državnih institucija ostvarivati svoja prava koja su uređena uredbama i zakonom. Primjetan je porast broja udruga koje putem svojih predstavnika zastupaju prava invalidnih osoba te ih obavještavaju o novim zakonima i pravima povezanim s njihovim dodatnim potrebama. Posebno se to odnosi na invalide rada koji zakonom mogu tražiti rad na pola radnoga vremena ili steći invalidsku mirovinu. Za ostale osobe s invaliditetom od velikog je značaja odluka o pravu na rad. Primjerice Hrvatski zavod za mirovinsko osiguranje donio je odluku da gluhonijema osoba ima pravo na beneficirani radni staž, a postupak za ostvarivanje tog prava pokreće se zahtjevom za utvrđivanjem radnog staža u povećanom trajanju koji se podnosi nadležnoj službi, tj. HZMO-u..$^{10}$ Bliska suradnja institucija i udruga, kao i podrška države, potrebna je kako bi se sredstva iz fondova EU iskoristila za unapređenje i povećanje kvalitete života i uključivanje osoba s invaliditetom u sve sfere društvenog života, pa tako i za ostvarivanje prava na rad. ${ }^{11}$

9 Popis stanovništva 2001. [citirano: 2019-1-24]. Dostupno na: . https://www.dzs.hr/hrv/censuses/census2001/census.htm.

10 Uvjeti pod kojima osoba s invaliditetom može ostvariti pravo na beneficirani radni staž. [citirano: 2019-1-24]. Dostupno na: http://www.in-portal.hr/in-portal-news/kutak-za-strucnjake/10098/ uvjeti-pod-kojim-osoba-s-invaliditetom-moze-ostvariti-pravo-na-beneficirani-radni-staz.

11 Isto. 


\section{Statistika - Knjižnice grada Zagreba}

Knjižnice grada Zagreba najveća su mreža narodnih knjižnica u Republici Hrvatskoj, ustanova koja svakom stanovniku grada Zagreba koji se učlani u bilo koju knjižnicu mreže omogućuje posudbu i korištenje građe i usluga u svakoj od svoje 42 knjižnice. KGZ redovito ažurira statističke podatke, a najnoviji polugodišnji podaci iz 2018. govore sljedeće: ukupan broj aktivnih članova u Knjižnicama grada Zagreba iznosi 115 103, a osobe s invaliditetom čine $2 \%$ članstva (upisane su ukupno 2442 osobe s invaliditetom) i one imaju pravo na besplatan upis. Besplatan upis ostvaruje se predočenjem invalidske knjižice ili potvrde koju izdaju udruge osoba s invaliditetom, npr. HSUTI (Hrvatski savez udruga tjelesnih invalida) ili HSUIR (Hrvatski savez udruga invalida rada), HVIDRA (Hrvatski ratni vojni invalidi Domovinskog rata Republike Hrvatske) itd. Suradnja knjižnica s udrugama kao što su Udruga za autizam, Udruga za promicanje inkluzije i Udruga djece s mentalnim oštećenjima pomaže da njihovi korisnici ostvare svoje pravo besplatnog upisa, iako o stavu njihovih skrbnika ovisi hoće li oni to pravo iskoristiti.

Detaljno se vode i statistički podaci o svakoj knjižnici ili o mreži knjižnica, pa su tako u mreži Knjižnice Tina Ujevića, od ukupnog broja članova koji je u prvoj polovini 2018. godine iznosio 7441 osobu, bile upisane 142 osobe s invaliditetom ( $2 \%)$. Postoci upisanih osoba s invaliditetom u odnosu na ukupan broj članova po ograncima iznose: Knjižnica Voltino-2 \% od 2713 članova, Knjižnica Staglišće$3 \%$ od 4584 člana, Knjižnica Prečko-3 \% od 3695 članova, Knjižnica Knežija-2 $\%$ od 3614 člana.

Mreža trešnjevačkih knjižnica ukupno broji 23136 članova, od toga 2 \% (494) upisanih osoba s invaliditetom ili $20 \%$ od ukupnog broja osoba s invaliditetom u odnosu na Knjižnice grada Zagreba. Ukupan broj posjeta osoba s invaliditetom u mreži Knjižnice Tina Ujevića iznosi 807 osoba.

Analizirajući podatke mreže Knjižnice Novi Zagreb može se vidjeti da je od ukupnog broja članova u prvoj polovini 2018. godine, koji je iznosio 4353, bilo 2,6 $\%$ (115) upisanih osoba s invaliditetom. Postoci upisanih osoba s invaliditetom u odnosu na ukupan broj članova po ograncima iznose: Knjižnica Dugave-2 \% od 3821 člana, Knjižnica Savski Gaj-3 \% od 4417 članova, Knjižnica Vjekoslava Majera-3 $\%$ od 3642 člana, Knjižnica Sloboština-2 \% od 1551 člana.

Mreža novozagrebačkih knjižnica ukupno broji 17994 člana, od toga 2,6 \% (484) upisanih osoba s invaliditetom ili $20 \%$ od ukupnog broja osoba s invaliditetom u odnosu na Knjižnice grada Zagreba. Ukupan broj posjeta osoba s invaliditetom u mreži Knjižnice Novi Zagreb iznosi 813 osoba.

Najnoviji podaci iz Izvještaja prvog polugodišta 2018. godine. (1. 1.-30. 6. 2018.) govore da te dvije mreže knjižnica imaju $40 \%$ upisanih osoba s invaliditetom od ukupnog broja upisanih osoba s invaliditetom u mreži Knjižnica grada Zagreba (slika 1). 


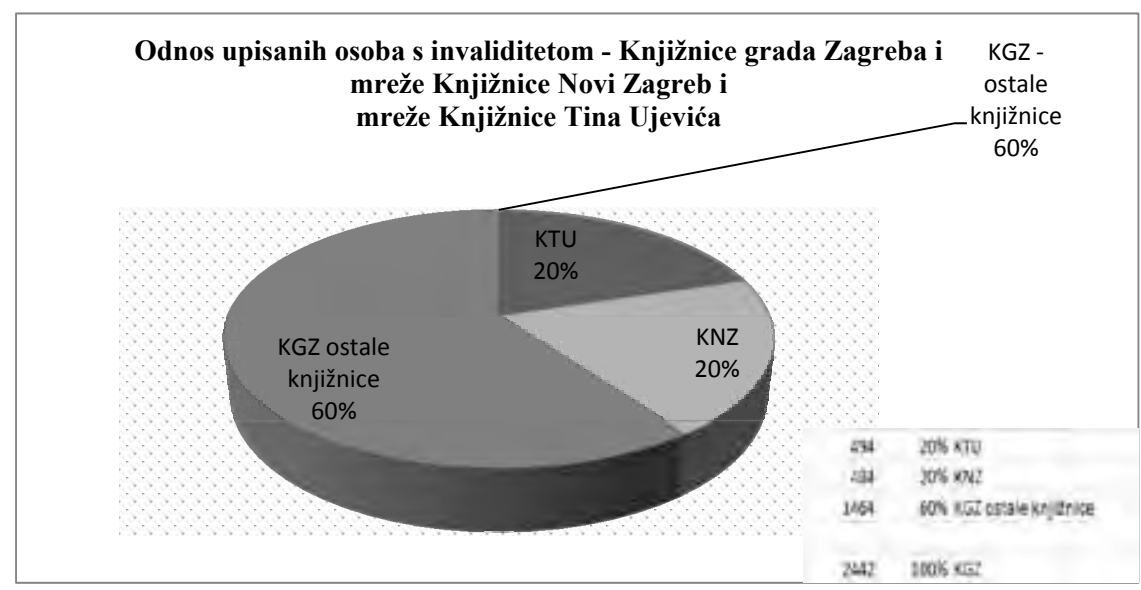

Slika 1. Odnos upisanih osoba s invaliditetom - Knjižnice grada Zagreba i mreže Knjižnice Novi Zagreb i Knjižnice Tina Ujevića

Podaci se nalaze se u programu ZaKi, a predaju se polugodišnje i godišnje u Matičnu službu koja ih potom objedinjuje i na temelju toga izrađuje godišnji Izvještaj o radu, koji je dostupan na mrežnim stranicama Knjižnica grada Zagreba.

Iz podataka koji su navedeni vidi se da u gradu Zagrebu ima 90260 osoba s invaliditetom, a u Knjižnice grada Zagreba u prvom polugodištu 2018. godine upisane su 2442 osobe s invaliditetom. Tako se narodnim Knjižnicama grada Zagreba u navedenom vremenskom periodu služilo $2,7 \%$ osoba s invaliditetom.

\section{Suradnja s udrugama - mreža Knjižnice Tina Ujevića}

Knjižnica Tina Ujevića od svoga osnutka surađuje s raznim udrugama osoba s invaliditetom i djecom s poteškoćama u razvoju. Uključivanjem u projekt „Knjižnica širom otvorenih vrata“" Knjižnica grada Zagreba, usmjerenim na poboljšanje kvalitete života invalidnih osoba, taj rad postaje valoriziran i prepoznat, što rezultira snažnijim i redovitijim međusobnim djelovanjem knjižnica i udruga osoba $s$ invaliditetom te uručenjem zahvala udruga knjižnicama. Suradnja s Udrugom za promicanje inkluzije kontinuirana je, što potvrđuje dugotrajno volontiranje jedne osobe s invaliditetom u Knjižnici Tina Ujevića koje traje već 16 godina, od 2002. godine. U tom razdoblju prati se rad spomenute osobe s invaliditetom, a uspostavljena suradnja između Udruge i Knjižnice Tina Ujevića očituje se u stručnoj podršci Udruge volonteru u njegovu lokalnom okruženju, i to najčešće na dnevnoj ili tjednoj bazi.

Kroz projekt „Knjižnica širom otvorenih vrata“ postala je vidljivija suradnja sa sljedećim udrugama: Udrugom za promicanje inkluzije i njezinom kreativ- 
nom radionicom UPI keramike, učeničkom zadrugom Grana Centra za autizam, Udrugom za pomoć osobama s mentalnom retardacijom grada Zagreba Vjeverica, Udrugom tetraplegičara i paraplegičara, Udrugom tjelesnih invalida, Udrugom gluhoslijepih osoba Dodir, Udrugom Debra, Udrugom Sunčev sjaj-dnevnim centrom za rehabilitaciju i radne aktivnosti osoba s posebnim potrebama, Udrugom Ozana, Hrvatskom udrugom za promicanje i razvoj tiflotehnike (HUPRT), danas Up2 date, Centrom za obrazovanje i rehabilitaciju Zagreb, Centrom za rehabilitaciju-ogranak Paunovac, Centrom za rehabilitaciju s obzirom na smještaj u stambenoj zajednici, Udrugom djece s tjelesnim i mentalnim oštećenjima Caritasove kuće „Blaženi Alojzije Stepinac“ u Brezovici, Bolnicom „Sv. Ivan“ Jankomir, Hrvatskom udrugom za školovanje pasa vodiča i mobilitet.

Specifičnost Knjižnice Tina Ujevića jest volontiranje spomenute osobe s poteškoćama u razvoju iz Udruge za promicanje inkluzije, koja se u 16 godina potpuno socijalizirala i pripada radnoj zajednici, dijeleći s ostalim djelatnicima radnu i privatnu svakodnevicu i iskustvo. Inkluzija - riječ koja znači biti uključen, obuhvaćen, pripadati, biti s drugima-suvremena je filozofija koja naglašava da je različitost u snazi, sposobnostima i potrebama prirodna i poželjna i da se samo takvim pristupom život osobama s invaliditetom može učiniti bogatijim, smislenijim i dostojnim životnog postojanja. Unatoč ljudskoj uskogrudnosti i predrasudama, djelatnici knjižnice nastoje pomoći da se volonter osjeća kao ravnopravan član zajednice. Osim obavljanja redovnih poslova (pomoćnih, kao što je slaganje knjiga na policama kako bi police bile uredne i složene, pomoć pomoćnim knjižničarima kod prijenosa knjiga, razvrstavanje knjiga na Dječjem odjelu uz nadzor knjižničara, pomoć pri pripremanju tribina i akcija uz sudjelovanje), volonter Udruge za promicanje inkluzije postao je i čitač. Redovno posuđuje do 3 knjige na mjesec uz stručnu sugestiju diplomiranog knjižničara informatora. Suradnja Udruge i Knjižnice traje tako već gotovo dva desetljeća, uz povremene izložbe radova članova Udruge, predstavljanje knjiga i likovne radionice. U radu s udrugama posebno je važna namjera susreta različitosti koja se ostvaruje kroz svaku knjižničnu akciju, bilo da se radi o likovnim izložbama i promocijama knjiga ili predstavljanjima rada udruga na kojima se upoznaje njihova organizacija, problematika... Predavanjima, razgovorima i druženjem senzibilizira se javnost i društvo te se teži rušenju predrasuda. Iz niza mnogobrojnih događanja treba izdvojiti izložbu likovnih radova djece $\mathrm{s}$ tjelesnim ili mentalnim poteškoćama Caritasove kuće „Blaženi A. Stepinac“ pod nazivom San u slapu koju je Knjižnica Knežija, ogranak Knjižnice Tina Ujevića, organizirala povodom Dana hrvatskih knjižnica 2012. godine. Otvorenje izložbe obilježeno je svečanom priredbom i primopredajom igračaka prikupljenih za djecu iz Caritasove kuće. Na tom događanju sudjelovala su i djeca iz okolnih osnovnih škola. U ožujku 2015. u Knjižnici Tina Ujevića uvodno predavanje o metodama Feldenkrais i Anat Baniel te radionicu za djecu s razvojnim teškoćama, roditelje i stručnjake održala je gospođa Ingrid Kecerin Ka- 
sumagić, kineziologinja. Prema mrežnim stranicama portala o metodama Feldenkrais i Anat Baniel, te su metode namijenjene osobama s oslabljenim funkcionalnim sposobnostima, koje redovitim korištenjem metoda ponovno uspijevaju iskusiti energičnija gibanja ili elastična i ritmična pulsiranja kroz tijelo, što osigurava čvrste kosti, podiže vitalnost i poziva na kretanje. ${ }^{12}$ Upoznavanje i senzibilizacija javnosti za problematiku osoba s posebnim potrebama u knjižnici se provodi i pomoću plakata, letaka i časopisa koje donose razne udruge s ciljem boljeg informiranja svekolike zajednice, a koji su iscrpni i vjerodostojni u informativnosti. Knjižnice kao komunikacijsko središte, koje koristi informaciju kao glavno sredstvo komunikacije u razmjeni znanja (ne uzimajući pritom u obzir pojavu kompjutorizacije i novih medija, nego usmenu komunikaciju i neposredno obraćanje korisnicima), trebaju posebno raditi na razvijanju komunikacijskih vještina knjižničara i njihovu njegovanju, naročito vještina ophođenja s osobama s invaliditetom. Stoga treba istaknuti tribinu i susret u Knjižnici Tina Ujevića s predsjednicom Hrvatskog saveza udruga tjelesnih invalida grada Zagreba dr. Mirjanom Dobranović, koja je vodila razgovor i edukaciju o svakodnevnom pristupanju i obraćanju osobama s invaliditetom, čime je uvelike pomogla sudionicima u spoznavanju i razumijevanju života osoba s invaliditetom. Brošura koju je tom prigodom poklonila Knjižnici objašnjava kako osobe s invaliditetom prihvaćaju svoju posebnost te kako s njom žive, a govori i o pravilnom ophođenju s takvim osobama. Istaknula je i knjigu za djecu „Bontončić“ kao dobar primjer literature uz pomoć koje djeca mogu shvatiti i naučiti prihvaćati različitost. Snažnu podršku tom događanju dao je i poslodavac KGZ-a, Gradski ured za kulturu, na čelu kojega je tada bila dogradonačelnica Ljiljana Kuhta. Od mnoštva ostalih događanja u mreži Knjižnice Tina Ujevića treba izdvojiti još i izložbu likovnih radova Irine Kučinar, osobe s paraplegijom, u Knjižnici Staglišće i susret s korisnicima Dnevnog centra za rehabilitaciju djece i mladeži Mali dom iz Zagreba, koji su sudjelovali u natjecanju na Malodomijadi koja se održava svake godine u lipnju te označava kraj edukacijsko-rehabilitacijskog razdoblja u Knjižnici Voltino te rad dvaju volontera u Knjižnici Prečko i Knjižnici Tina Ujevića, koji je već spomenut. Knjižnica Tina Ujevića uspostavila je preko Hrvatskog saveza udruga tjelesnih invalida (HSUTI) suradnju s Udrugom Debra (udruga osoba oboljelih od bulozne epidermolize). Članovima Udruge omogućena je javna prezentacija njihovih djelatnosti i aktivnosti na polju književnosti, glazbe i likovne umjetnosti. Ujedno se korisnicima knjižnice pružaju informacije o Udruzi, tj. pomoći za njezine članove, te se radi na senzibilizaciji javnosti za postojanje vrlo teških i rijetkih bolesti. Razumljivo je, $s$ obzirom na sve izneseno, kako za pojedine osobe postoje različite zapreke u čitanju i razumijevanju građe, bilo u određenom formatu ili određenog oblika sa-

12 Feldenkrais i Anat Baniel metoda: radionica za roditelje i stručnjake. [ citirano: 2019-124]. Dostupno na: http://www.prirodakretanja.eu/index.php?option $=$ com_content\&view $=$ article\&id=103\&Itemid $=183$. 
držaja. Shodno tomu, potrebno je ponovno se osvrnuti na propisane smjernice IFLA-e i UNESCO-a koje je važno slijediti u formiranju novih knjižničnih zbirki. To su smjernice koje se odnose na kriterije za zbirke i oblike građe koji se mogu uključiti u zbirku narodne knjižnice. ${ }^{13}$ Posebne službe (nabava, obrada) moraju osigurati građu za one korisnike koji se iz bilo kojeg razloga ne mogu služiti redovitim uslugama i građom. Tradicionalna međunarodna podjela posebne korisničke grupe dijeli na osobe $\mathrm{s}$ fizičkim i mentalnim poteškoćama, slijepe i slabovidne osobe, osobe s različitim poteškoćama u čitanju i pisanju, odnosno učenju, gluhe i nagluhe osobe te gluhoslijepe osobe. Knjižnice zato sustavno počinju uvoditi građu namijenjenu upravo takvim korisnicima, npr. građu laganu za čitanje, format daisy i zvučne knjige, pri čemu knjižnice usko surađuju s izdavačkim kućama. Pritom se u rad unose sve potrebne promjene koje, na neki način, odstupaju od uvriježenih pravila poslovanja, a koje su nužne u obradi takve građe i njezinu davanju na korištenje. U tome u znatnoj mjeri pomaže nedavno objavljeni Marakeški ugovor jer se njime utvrđuje niz međunarodnih pravila kojima se osigurava postojanje ograničenja ili iznimke od pravila o autorskim pravima u korist osoba koje su slijepe, imaju oštećenje vida ili druge poteškoće u korištenju tiskanim materijalima. Njime se omogućuje i prekogranična razmjena primjeraka objavljenih djela izrađenih u dostupnom formatu (Ugovor iz Marakeša ${ }^{14}$ ). Ulazak nove vrste građe u knjižnicu, u novim formatima koji dopunjuju i obogaćuju postojeće knjižnične zbirke, potrebno je odraditi kvalitetno. U to je uključena pravilna i dobro osmišljena nabava, obrada - naročito klasifikacija i signiranje takve građe, što rezultira promišljenim smještajem unutar knjižnice. Pomoć u izgradnji zbirki knjižnicama omogućuje i suradnja s ustanovama kao što su Centar UP2DATEudruga za promicanje i razvoj tiflotehnike, Udruga Visoki jablani iz Rovinja i Udruga Poseban prijatelj iz Dubrovnika, uz financijsku podršku Ministarstva znanosti, obrazovanja i sporta te uz pomoć javnih osoba poput glumaca i autora. $U$ nekoliko navrata spomenute udruge prezentirale su u Knjižnici Tina Ujevića knjige za invalidne, točnije, slijepe i slabovidne osobe u nekoliko različitih formata (kao tiskanu građu, građu na Brailleovu pismu te zvučnu knjigu) uz čitanje glumaca i predstavljanje autora ili prevoditelja. Među ostalima, treba istaknuti knjigu koja je izašla kao tiskana knjiga i kao zvučna građa. Radi se o knjizi „Štagalj na jezeru Gun“ Johnnieja Tuitela i Sharon Lamson Tuitel. O vrijednosti i uspješnosti predane $\mathrm{i}$ iskrene suradnje knjižnice s različitim udrugama svjedoče dobivene pisane zahvale: Hrvatskog saveza udruga tjelesnih invalida grada Zagreba, Centra UP2DATE, Udruge za pomoć osobama s mentalnom retardacijom grada Zagreba i Hrvatske udruge gluhoslijepih osoba Dodir.

\footnotetext{
13 Narodna knjižnica. Nav. dj., str. 44-47.

14 Ugovor iz Marakeša o pristupu slijepih i slabovidnih osoba objavljenim djelima: EU otvorio put za ratifikaciju. [citirano: 2019-1-24]. Dostupno na: https://www.consilium.europa.eu/hr/press/ press-releases/2017/05/10/marrakesh-treaty/.
} 


\section{Mreža Knjižnice Novi Zagreb - suradnja s udrugama}

Poput mreže Knjižnice Tina Ujevića, slične aktivnosti provode knjižnice mreže Novi Zagreb.

Od samog osnutka mreže Knjižnica Novog Zagreba surađuje se s raznim ustanovama koje se bave osobama kojima je potreban drukčiji pristup i angažman unutar knjižničarske struke. Na samim počecima akcije se nisu održavale kontinuirano, ali se surađivalo s Udrugom Ozana, Centrom za autizam, Centrom za odgoj i obrazovanje Vinko Bek i dr. Treba spomenuti dugogodišnju korisnicu koja je redovito pohađala aktivnosti u igraonici Knjižnice Novi Zagreb, a knjižnica joj je tijekom cijelog života bila ustanova u kojoj je najviše boravila izvan svoje obitelji. Mreža Knjižnice Novi Zagreb također se uključuje u projekt „Knjižnica šrom otvorenih vrata" u svrhu valorizacije i sustavnog organiziranja takva rada, kao i mreža Knjižnice Tina Ujevića.

Tijekom godina Knjižnica Savski Gaj osmislila je program koji je nazvan Moj sat vremena čitanja (radionice čitanja za mlade s intelektualnim poteškoćama). Program kontinuirano uključuje mlade s invaliditetom iz Dnevnog centra za rehabilitaciju i radnu terapiju Egida, a povremeno u njemu sudjeluju i djeca iz lokalnih osnovnih škola.

U grupi je u prosjeku 15 korisnika u dobi od 20 do 40 godina. Program se sastoji od različitih radionica koje su uglavnom vezane uz knjigu, a osnovno je čitanje naglas korisnika različitih intelektualnih sposobnosti i različitih vještina čitanja. Nakon čitanja slijedi razgovor o pročitanom ili o nekoj aktualnoj temi. Svaki put pročita se neki kraći tekst iz književnog djela. Biraju se tekstovi koji će ipak biti u skladu s kronološkom dobi korisnika, a to je od 20do 30 godina, iako to nije uvijek nužno. Dvaput je u sklopu radionice organiziran književni susret $s$ piscem. Broj susreta u proteklim godinama bio je oko 180 , a sudjelovalo je oko 2700 korisnika.

Knjižnica Sloboština posebno se ističe dugotrajnom suradnjom s Udrugom za cerebralnu paralizu (CeDePe). Treba napomenuti kako Knjižnica Sloboština nakon preseljenja u novi prostor 2007. zadovoljava sve uvjete ili sve dodatne potrebe za osobe s invaliditetom: olakšan je pristup knjižnici pomoću rampe, osigurano je dizalo i prilagođen sanitarni čvor te police, koje su svojom visinom pristupačne osobama u invalidskim kolicima. Suradnja se ostvaruje kroz organizirane aktivnosti za djecu i odrasle članove društva u vidu promocija knjiga, kreativnih radionica, nastupa autora...

U okviru CeDePea organizira se dramska skupina (od 2013. g.) pod nazivom Ekipa za 7 koja provodi dramske aktivnosti i nastupe. Ekipa za 7 redovito sudjeluje na INKAZ-u - susretima kulturno-umjetničkih sastava za djecu i mlade s teškoćama, međunarodnoj smotri glazbenog, scenskog i plesnog stvaralaštva osoba s invaliditetom. U Knjižnici Sloboština redovito se obilježava 5. svibnja, Nacional- 
ni dan osoba s cerebralnom paralizom, čime se povezuje rad udruge s lokalnom zajednicom i osnovnom školom, što i je cilj takvih susreta.

Mreža Knjižnice Novi Zagreb također je s ponosom okrunila svoju suradnju s udrugama dobivanjem pisanih zahvala, npr. Udruge CeDePe i Udruge Ozana.

\section{Zaključak}

Inkluzivne usluge u narodnim knjižnicama nisu novost. One se provode dugi niz godina, a zadnja dva desetljeća usustavile su se kroz suradnju s udrugama osoba s invaliditetom, ali i bitno poboljšale naglim razvojem novih tehnologija. Agenda 2030 sadrži 17 globalnih ciljeva i 169 pridruženih ciljeva održivog razvoja koji su osmišljeni kako bi se uspješno dovršilo ono što je započeto Milenijskim ciljevima (iz 2001.), i to tako da nitko ne bude isključen iz mogućnosti realizacije boljeg i kvalitetnijeg života. Zadaća narodnih knjižnica odnosi se posebno na cilj 4: osigurati uključivo i kvalitetno obrazovanje te promovirati mogućnosti cjeloživotnog učenja i cilj 10: smanjiti nejednakost unutar država i između njih. Primjeri dobre prakse prikazani u ovom članku postaju redovna djelatnost narodnih knjižnica. Ta djelatnost ne uključuje samo nova znanja i upravljanje informacijama djelatnika narodne knjižnice već se očituje i u tome da knjižničar, osim što je informacijski stručnjak-homo universalis, treba biti i-homo humanus. Zato za kraj ovoga članka navodimo promociju pjesama Gogina zbirka u Knjižnici Tina Ujevića autorice Gordane Huzek iz Udruge za promicanje inkluzije na kojoj su gostovali Valerija Jelčić, prof. defektologije, Iva Čulo, dipl. defektolog - koordinator, Neven Dužević, glazbenik i pjesnik te Lada Žigo, književnica i novinarka, koja je tom prigodom iz svog predgovora knjizi istaknula riječi koje najbolje opisuju cjelokupan rad narodnih knjižnica na jednom od područja inkluzije te podsjećaju djelatnike knjižnice kako su važni sudionici u stvaranju boljeg društva:

„(...) Pjesnikinja svoje vedre pjesme ne prinosi ambiciozno na "oltar poezije" nego ih zatajno pridonosi na "oltar ljudskosti". A to je veoma važno. Jer, dok je "oltar poezije" prepun pjesama i autora, "oltar ljudskosti”, na žalost, još uvijek stoji (...) poluprazan.“ 


\section{LITERATURA}

Anić, V.; I. Goldstein. Rječnik stranih riječi. Zagreb: Novi liber, 2000.

Feldenkrais i Anat Baniel metoda: radionica za roditelje i stručnjake. [ citirano: 20191-24]. Dostupno na: http://www.prirodakretanja.eu/index.php?option=com_content\&view=article\&id=103\&Itemid=183.

Mihanović, V. Invaliditet u kontekstu socijalnog modela. // Hrvatska revija za rehabilitacijska istraživanja 47, 1 (2011), 72-86.

Narodna knjižnica: IFLA-ine i UNESCO-ove smjernice za razvoj službi i usluga / priredila radna skupina Sekcije za narodne knjižnice na čelu s Philipom Gillom ; [s engleskoga prevela Irena Kranjec] Zagreb: Hrvatsko knjižničarsko društvo, 2003.

Novi izazov: globalni ciljevi održivog razvoja do 2030. Zagreb: Odraz, 2015. [citirano: 2019-1-24]. Dostupno na: http://www.odraz.hr/media/330673/globalni\%20ciljevi_ or_final_web.pdf.

Popis stanovništva 2001. [citirano: 2019-1-24]. Dostupno na: https://www.dzs.hr/hrv/ censuses/census2001/census.htm.

Ugovor iz Marakeša o pristupu slijepih i slabovidnih osoba objavljenim djelima: EU otvorio put za ratifikaciju. [citirano: 2019-1-24]. Dostupno na: https:/www.consilium.europa.eu/hr/press/press-releases/2017/05/10/marrakesh-treaty/.

Uvjeti pod kojima osoba $\mathrm{s}$ invaliditetom može ostvariti pravo na beneficirani radni staž. [citirano: 2019-1-24]. Dostupno na: http://www.in-portal.hr/in-portal-news/ kutak-za-strucnjake/10098/uvjeti-pod-kojim-osoba-s-invaliditetom-moze-ostvariti-pravo-na-beneficirani-radni-staz.

Zovko, G. Invalidi i društvo. // Revija za socijalnu politiku 6, 2 (1999), 105-117. 